\title{
Penerapan Model Pembelajaran Inkuiri Berbasis Google Classroom untuk Meningkatkan Kemampuan Berfikir Kritis dan Aktivitas Belajar PAI dan Budi Pekerti pada Peserta Didik SMA Negeri 1 Selong
}

\author{
Asmuni \\ SMA Negeri 1 Selong, Kabupaten Lombok Timur - Provinsi NTB \\ Corresponding Author. Email: asmuni7784@gmail.com
}

\begin{abstract}
This study aims to apply a google classroom-based inquiry learning model to improve critical thinking skills and learning activities of Islamic Education and Characteristics of munakahat material in SMAN 1 Selong students. This research method is a classroom action research. The subjects of this study were 35 students of class XII MIPA-4. Data collection techniques were carried out by tests and observations. The collected data were analyzed descriptively qualitatively. The results obtained were (1) the increase in critical thinking skills of students as evidenced by the learning outcomes of the original knowledge aspects at an average of 72 , increased to 83 in the first cycle, and increased again to 85 in the second cycle, while the learning outcomes of the aspects of learning. Initial skills at initial conditions averaged 69, increased to 78 in cycle I, and increased again to 86 in cycle II. For the percentage of learning completeness (knowledge), students who completed from the initial conditions were $22.86 \%$ ( 8 people), increased by $62.86 \%$ ( 22 people) in cycle I, and increased again $91.43 \%$ (32 people) in the cycle II. Completeness of learning (skills), students who completed from the initial conditions $22.86 \%$ (8 people), increased $62.86 \%$ (22 people) in cycle I, and increased again $91.43 \%$ (32 people) in cycle II; and (2) increased learning activities of students as evidenced by an increase in learning activities.
\end{abstract}

Abstrak: Penelitian ini bertujuan menerapkan model pembelajaran inkuiri berbasis google classroom untuk meningkatkan kemampuan berfikir kritis dan aktivitas belajar PAI dan Budi Pekerti materi munakahat pada peserta didik SMAN 1 Selong. Metode penelitian ini adalah penelitian tindakan kelas. Subyek penelitian ini adalah peserta didik kelas XII MIPA-4 yang berjumlah 35 orang. Teknik pengumpulan data dilakukan dengan tes dan observasi. Data yang terkumpul dianalisis secara deskriptif kualitatif. Hasil penelitian yang diperoleh adalah (1) meningkatnya kemampuan berfikir kritis peserta didik yang dibuktikan dengan hasil belajar aspek pengetahuan semula pada kondisi awal rata-rata 72 , meningkat menjadi 83 pada siklus I, dan meningkat lagi menjadi 85 pada siklus II, sedangkan hasil belajar aspek keterampilan semula pada kondisi awal rata-rata 69, meningkat menjadi 78 pada siklus I, dan meningkat lagi 86 pada siklus II. Untuk persentase ketuntasan belajar (pengetahuan), peserta didik yang tuntas dari kondisi awal 22,86\% (8 orang), meningkat 62,86\% (22 orang) pada siklus I, dan meningkat lagi 91,43\% (32 orang) pada siklus II. Ketuntasan belajar (keterampilan), peserta didik yang tuntas dari kondisi awal 22,86\% (8 orang), meningkat 62,86\% (22 orang) pada siklus I, dan meningkat lagi $91,43 \%$ (32 orang) pada siklus II; dan (2) meningkatnya aktivitas belajar peserta didik yang dibuktikan adanya peningkatan aktivitas belajar.
Article History

Received: 24-03-2021

Revised: 05-04-2021

Published: 14-04-2021

Key Words:

Inquiry, Google

Classroom, Critical

Thinking, Learning

Activities.

Sejarah Artikel

Diterima: 24-03-2021

Direvisi: 05-04-2021

Diterbitkan: 14-04-2021

\section{Kata Kunci:}

Google Classroom; Berfikir Kritis; Aktivitas Belajar

How to Cite: Asmuni, A. (2021). Penerapan Model Pembelajaran Inkuiri Berbasis Google Classroom untuk Meningkatkan Kemampuan Berfikir Kritis dan Aktivitas Belajar PAI dan Budi Pekerti pada Peserta Didik SMA Negeri 1 Selong. Jurnal Teknologi Pendidikan : Jurnal Penelitian dan Pengembangan Pembelajaran, 6(1). doi:https://doi.org/10.33394/jtp.v6i1.3593 


\section{Pendahuluan}

Keterampilan berpikir kritis (Critical Thinking) merupakan salah satu dari 10 keterampilan dasar yang perlu disiapkan dan dikembangkan oleh siswa agar dapat bertahan dan berhasil di masa sekarang dan masa yang akan datang (Koroh \& Ly, 2020 \& Erwanto, 2020). Kemampuan peserta didik dalam menjawab soal yang mengacu pada kemampuan berfikir kritis masih rendah, masih banyak mereka yang tidak dapat mengkonstruk apa yang telah disampaikan oleh guru. Selain itu, tampaknya peserta didik lebih memaknai pembelajaran PAI dan Budi Pekerti sebagai sebuah materi yang sarat hafalan. Sementara peserta didik lebih diarahkan lebih memahami dan menemukan sendiri konsep atau pengetahuan yang ada.

Permasalahan faktual lain yang ikut menjadi pemicu rendahnya kemampuan berfikir kritis adalah strategi atau model pembelajaran yang diterapkan guru tampaknya kurang mendukung peserta didik untuk aktif belajar, kurang memfasilitasi mereka dalam proses pengembangan berfikir, seperti menggali masalah, memecahkan masalah dalam pembelajaran dan menemukan pengetahuan sendiri terkait materi pembelajaran. Peserta didik hanya mendengar, mencatat, berusaha mengingat tanpa memahami dan memaknai informasi yang diperoleh dalam pembelajaran.

Hal ini mengakibatkan rendahnya kemampuan berfikir kritis peserta didik dalam menyelesaikan masalah, yang tentu berdampak pada rendahnya aktivitas dan hasil belajar peserta didik. Sementara tuntutan kurikulum 2013 bahwa pengetahuan itu harus digali dan direkonstruksi sendiri oleh peserta didik. Karena itu proses pembelajaran harus interaktif, inspiratif, menyenangkan, menantang, dan memotivasi peserta didik untuk berpartisipasi aktif serta memberikan ruang yang cukup bagi prakarsa, kreativitas dan kemandirian sesuai dengan bakat, minat, dan perkembangan fisik serta psikologis peserta didik (Permendinkas Nomor 41 tahun 2007). Dengan kata lain dalam pembelajaran peserta didik harus aktif mencari, mengolah, mengkonstruksi, dan menggunakan pengetahuan. Guru harus merancang pembelajaran yang mendorong peserta didik dapat mengkonstruksi pengetahuan melalui aktivitas memecahkan masalah, menemukan informasi/data, berfikir secara kritis dan merumuskan kesimpulan.

Karena itu, perlu ada kreativitas dan inovasi seorang guru sebagai penentu utama dalam keberhasilan pembelajaran. Terkait dengan peningkatan kemampuan berfikir kritis dan peningkatan aktivitas belajar peserta didik, salah satu model pembelajaran yang relevan untuk pembelajaran PAI dan Budi Pekerti adalah menerapkan model pembelajaran inkuiri (inquiry based learning). Model pembelajaran inkuiri adalah rangkaian kegiatan pembelajaran yang menekankan pada proses berfikir secara kritis dan analitis untuk mencari dan menemukan sendiri jawaban dari suatu masalah yang dipertanyakan. Peserta didik berperan untuk menemukan sendiri inti dari materi pelajaran itu sendiri (Sanjaya, 2006; Harni, 2021; Nurkhasanah, 2019)

Hasil penelitian Rahmatsyah dan Simamora sebagaimana dikutip oleh Nurdyiansyah dan Eni (2016) menyatakan bahwa model pembelajaran inkuiri memiliki tahapan pembelajaran yang membangkitkan keaktifan peserta didik sehingga selain aktivitas meningkat, hasil belajar juga meningkat. Majid (2014) menyatakan inkuiri diperoleh dari sikap tahap mengamati, menemukan dan merumuskan masalah, mengajukan hipotesis, mengumpulkan data, menganalisis data, dan menarik kesimpulan. Jadi, dapat ditegaskan bahwa dalam inkuiri apa yang dimiliki peserta didik baik pengetahuan maupun keterampilan diperoleh dari hasil menemukan sendiri, bukan dari hasil mengingat apa yang disampaikan guru. 
Guru dalam menerapkan model pembelajaran inkuri dengan mengikuti sintak berikut: a) mengamati berbagai fenomena alam yang akan memberikan pengalaman belajar kepada peserta didik; b) mengajukan pertanyaan tentang fenomena yang dihadapi untuk melatih peserta didik mengeksplorasi fenomena melalui berbagai sumber; c) mengajukan dugaan (hipotesis) untuk melatih peserta didik dalam mengasosiasi atau melakukan penalaran terhadap kemungkinan jawaban dari pertanyaan yang diajukan; d) mengumpulkan data yang terakait dengan dugaan atau pertanyaan yang diajukan; dan e) merumuskan kesimpulan berdasarkan data yang telah diolah atau dianalisis (Kemdikbud, 2017).

Penerapan langkah-langkah pembelajaran ini dengan tepat, diprediksi kuat peserta didik terlibat secara aktif mengikuti seluruh rangkaian kegiatan pembelajaran, sehingga pembelajaran menjadi berhasil. Mulyasa (2002) menjelaskan bahwa pembelajaran dikatakan berhasil dan berkualitas apabila seluruhnya atau setidak-tidaknya sebagian besar $(75 \%)$ peserta didik terlibat secara aktif, baik fisik, mental maupun sosial dalam proses pembelajaran. Jadi, pergerakan guru hanya sebagai fasilitator dan motivator bagi peserta didik dalam pembelajaran. Selanjutnya, dalam penelitian ini indikator-indikator kemampuan berfikir kritis yang ditetapkan terbatas pada merumuskan masalah, merumuskan hipotesis, mengumpulkan data, menganalisis data, dan merumuskan kesimpulan.

Penerapan pembelajaran inkuiri dalam penelitian ini dilakukan secara daring (dalam jaringan) dengan memanfaatkan e-learning melalui google classroom. Pilihan dalam pelaksanaan pembelajaran daring (work from home) merupakan implementasi salah satu kebijakan pemerintah di sektor pendidikan sebagai akibat mewabahnya pandemi coronoa virus disease 2019 (Covid-19) yang masih terjadi (Asmuni, 2020). Adapun penelitian ini bertujuan menerapkan model pembelajaran inkuiri berbasis google classroom untuk meningkatkan kemampuan berfikir kritis dan aktivitas belajar PAI dan Budi Pekerti materi munakahat pada peserta didik kelas XII MIPA-4 SMAN 1 Selong tahun pelajaran 2020/2021.

\section{Metode Penelitian}

Prosedur penelitian yang digunakan adalah penelitian tindakan kelas yang dilakukan dalam daur siklus, yang terdiri atas empat kegiatan, yaitu perencanaan tindakan, pelaksanaan tindakan, pengamatan, dan refleksi. Subjek yang dikenai tindakan penelitian adalah peserta didik kelas XII MIPA-4 sebanyak 35 orang dengan rincian peserta didik laki-laki 12 orang dan perempuan 23 orang. Penelitian ini dilaksanakan dalam dua siklus, di mana siklus I dan siklus II masing-masing dilaksanakan dua kali pertemuan. Jenis data yang diambil dalam penelitian ini terdiri dari data kemampuan berfikir kritis peserta didik, aktivitas belajar peserta didik, dan tindakan guru dalam melaksanakan pembelajaran.

Teknik pengumpulan data yang digunakan dalam penelitian ini adalah teknik tes dan observasi. Teknik tes yang merupakan aspek pengetahuan digunakan untuk mengambil data kemampuan berfikir kritis peserta didik. Tes berbentuk tes tulis (uraian) yang berada pada level higher order thingking skills (HOTS) yang diberikan di setiap akhir siklus. Sedangkan penilaian aspek keterampilan berbentuk penilaian proyek yang disertai dengan rubrik penilaiannya. Peserta didik mengikuti penilaian proyek ini secara berkelompok, dan diberikan setelah berakhir tiap siklus dengan limit waktu pengerjaan yang telah ditentukan. Teknik observasi digunakan untuk mengetahui aktivitas belajar peserta didik dan tindakan guru selama pembelajaran. Observasi dilakukan dengan menggunakan pedoman observasi dan sebagai observer dalam penelitian ini adalah guru PAI lain. 
Data kemampuan berfikir peserta didik diketahui dari hasil tes setelah dianalisis secara deskriptif. Data hasil penilaian baik pengetahuan maupun keterampilan ditetapkan dengan kriteria bahwa (1) peserta didik ditetapkan tuntas belajar secara individu apabila telah mencapai nilai kriteria ketuntasan minimal (KKM 79) baik aspek pengetahuan maupun keterampilan, dan (2) ketuntasan belajar klasikal ditetapkan apabila $\geq 85 \%$ peserta didik mencapai ketuntasan belajar.

Data yang diperoleh dari hasil lembar observasi aktivitas belajar peserta didik selama pembelajaran dianalisis dengan mengklasifikasi kriteria keaktifan peserta didik. Kriteria keaktifan siswa pada pembelajaran berdasarkan hasil persentase yang diperoleh, hasil pengembangan dari Purwanto (2012:), yaitu:

\section{Tabel 1. Kriteria Aktivitas Belajar}

\begin{tabular}{|c|c|}
\hline Persentase & Kriteria \\
\hline $75 \%-100 \%$ & Sangat Aktif \\
\hline $65 \%-74 \%$ & Aktif \\
\hline $56 \%-64 \%$ & Cukup Aktif \\
\hline $0 \%-55 \%$ & Kurang Aktif \\
\hline
\end{tabular}

Khusus untuk aktivitas guru, perlu ditegaskan di sini bahwa isian instrumen pengamatan hanya akan menghasilkan catatan-catatan dalam bentuk narasi. Aspek-aspek yang menjadi fokus pengamatan tidak perlu dinilai apalagi kemudian dikategorikan untuk ditentukan pada kualitas baik atau kurang dan sebagainya karena itu tidak perlu. Penelitian tindakan kelas (PTK) tidak bertujuan menilai guru peneliti pada predikat baik atau lainnya. Cukup catatan hasil pengamatan tindakan guru ini menjadi bukti tertulis atau rekam jejak proses pembelajaran yang dilakukan guru peneliti untuk setiap pertemuan dalam siklus.

Indikator keberhasilan dalam penelitian ini dapat ditetapkan sebagai berikut: (a) kemampuan berfikir kritis peserta didik rata-rata kelasnya mengalami peningkatan dari satu siklus ke siklus berikutnya; (b) ketuntasan belajar individu telah mencapai nilai kriteria ketuntasan minimal (ditetapkan KKM 79), sedangkan ketuntasan belajar klasikal, persentase peserta didik yang tuntas belajar $\geq 85 \%$ dari seluruh jumlah peserta didik; dan (c) aktivitas peserta didik dalam pembelajaran minimal mencapai kategori aktif serta mengalami peningkatan rata-rata skor pada tiap siklusnya.

\section{Hasil Penelitian dan Pembahasan Kemampuan Berfikir Kritis}

Pada kondisi awal (sebelum penerapan siklus), peserta didik diberikan tes untuk mengetahui kemampuan awal terhadap materi pelajaran. Hasil belajar (aspek pengetahuan) pada kondisi awal diperoleh rata-rata sebesar 72. Setelah diterapkan siklus I diperoleh ratarata hasil belajar siklus I sebesar 83. Persentase perbandingan peningkatan dari kondisi awal ke siklus I mencapai 15,28\%. Dimana nilai tertinggi yang dicapai peserta didik dari kondisi awal sebesar 90, naik menjadi 94 pada siklus I. Untuk nilai terendah dari kondisi awal sebesar 45 naik menjadi 58. Dari peserta didik yang berjumlah 35 orang, banyaknya yang tuntas pada kondisi awal hanya 15 orang $(42,86 \%)$, meningkat menjadi 27 orang $(77,14 \%)$, sementara peserta didik yang belum tuntas sebanyak 20 orang $(57,14 \%)$ pada kondisi awal, berkurang menjadi 8 orang $(22,86 \%)$ pada siklus I.

Dengan demikian terjadi peningkatan rata-rata hasil belajar peserta didik. Terjadinya peningkatan rata-rata sebagai dampak diterapkannya pembelajaran inkuiri berbasis google classroom. Meskipun sejumlah kendala dan permasalahan yang ditemui selama pembelajaran 
siklus I baik permasalahan teknis maupun penerapan pembelajaran inkuiri dengan menggunakan aplikasi google classroom. Secara daring peserta didik difasilitasi dan dibimbing oleh guru, bagaimana menemukan dan merumuskan masalah, mengumpulkan data, menganalisis data, dan merumuskan kesimpulan. Peserta didik cukup antusias mengikuti pembelajaran, terbukti rasa ingin tahu (kuriositas) peserta didik muncul, dengan mengajukan sejumlah pertanyaan. Pertanyaan yang sering muncul adalah bagaimana menemukan masalah, mengumpulkan dan menganalisis datanya. Keadaan demikian menggambarkan peserta didik aktif belajar, meskipun sejumlah peserta didik yang lain juga belum menunjukkan belajar aktif. Belum diketahui apakah mereka sudah memahami prosedur kerja (tertuang di LKPD) yang diberikan atau belum. Karena itu guru terus mengingatkan dan memotivasi untuk bertanya dan bertanya, agar kegiatan yang tertuang dalam LKPD dilakukan dengan benar dan mencapai hasil yang maksimal.

Selanjutnya, hasil belajar peserta didik dari kondisi awal rata-rata 72, meningkat 83 pada siklus I, meningkat lagi menjadi 85 pada siklus II. Persentase peningkatannya sebesar $2,41 \%$. Nilai tertinggi yang dicapai dari kondisi awal 90, meningkat 94 pada siklus I, meningkat lagi menjadi 97 pada siklus II. Nilai terendah yang diperoleh dari kondisi awal 45, naik menjadi 58 pada siklus I, naik lagi menjadi 63 pada siklus II. Untuk ketuntasan, banyaknya peserta didik yang tuntas dari kondisi awal sejumlah 15 orang (42,86\%), meningkat 27 orang $(77,14 \%)$ pada siklus I, meningkat lagi menjadi 31 orang $(88,57 \%)$ pada siklus II dengan persentase peningkatan sebesar $14,81 \%$. Sementara peserta didik yang belum tuntas dari kondisi awal 20 orang $(57,14 \%)$, berkurang signifikan menjadi 8 orang $(22,86 \%)$ pada siklus I, dan berkurang lagi menjadi 4 orang $(11,43 \%)$ pada siklus II.

Lebih jelas, keseluruhan perbandingan hasil belajar (pengetahuan) pada kondisi awal, siklus I dan siklus II seperti tampak pada tabel dan diagram berikut.

Tabel 2. Hasil Belajar Pengetahuan Kondisi Awal, Siklus I dan Siklus II

\begin{tabular}{|l|c|c|c|}
\hline \multicolumn{1}{|c|}{ Keterangan } & $\begin{array}{c}\text { Kondisi } \\
\text { Awal }\end{array}$ & $\begin{array}{c}\text { Siklus } \\
\text { I }\end{array}$ & $\begin{array}{c}\text { Siklus } \\
\text { II }\end{array}$ \\
\hline Nilai rata-rata & 72 & 83 & 85 \\
\hline Nilai tertinggi & 90 & 94 & 96 \\
\hline Nilai terendah & 45 & 58 & 63 \\
\hline Banyak peserta didik yang tuntas & 15 & 27 & 31 \\
\hline $\begin{array}{l}\text { Banyak peserta didik yang belum } \\
\text { tuntas }\end{array}$ & 20 & 8 & 4 \\
\hline
\end{tabular}

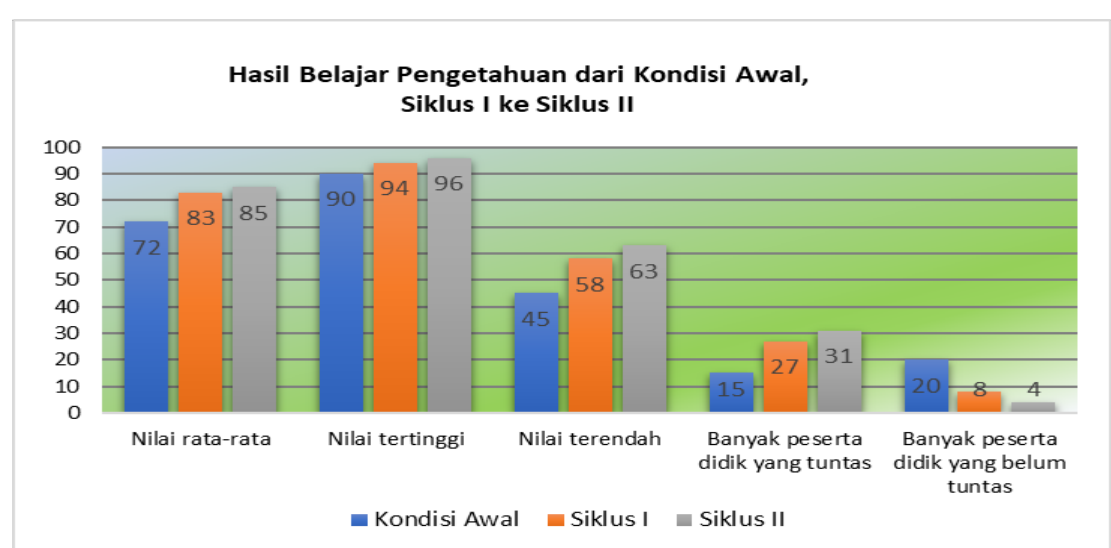

Gambar 1. Hasil Belajar Pengetahuan dari Kondisi Awal, Siklus I dan Siklus II 
Berikutnya hasil belajar peserta didik aspek keterampilan dari kondisi awal rata-rata yang diperoleh sebesar 69, meningkat pada siklus I dengan rata-rata sebesar 78, meningkat lagi menjadi 86 pada siklus II. Persentase peningkatannya sebesar 10,26\%. Nilai tertinggi yang dicapai pada siklus I sebesar 89, meningkat menjadi 96 pada siklus II. Nilai terendah yang diperoleh pada siklus I sebesar 63, naik menjadi 74 pada siklus II. Untuk ketuntasan belajar, banyaknya peserta didik yang tuntas dari kondisi awal sebanyak 8 orang $(22,86 \%)$, meningkat 22 orang $(62,86 \%)$ pada siklus I, meningkat lagi menjadi 32 orang $(91,43 \%)$ pada siklus II. Persentase peningkatannya sebesar $45,45 \%$. Sementara peserta didik yang belum tuntas dari kondisi awal 27 orang $(77,14 \%)$, berkurang menjadi 13 orang $(37,14 \%)$ pada siklus I, kemudian berkurang lagi menjadi 3 orang $(8,57 \%)$ pada siklus II.

Lebih jelas, perbandingan hasil belajar (keterampilan) dari kondisi awal, siklus I dan siklus II dapat disajikan dalam tabel dan diagram berikut.

Tabel 3. Hasil Belajar Keterampilan dari Kondisi Awal, Siklus I dan Siklus II

\begin{tabular}{|l|c|c|c|}
\hline \multicolumn{1}{|c|}{ Keterangan } & $\begin{array}{c}\text { Kondisi } \\
\text { Awal }\end{array}$ & $\begin{array}{c}\text { Siklus } \\
\text { I }\end{array}$ & $\begin{array}{c}\text { Siklus } \\
\text { II }\end{array}$ \\
\hline Nilai rata-rata & 69 & 78 & 86 \\
\hline Nilai tertinggi & 85 & 89 & 96 \\
\hline Nilai terendah & 48 & 63 & 74 \\
\hline Banyak peserta didik yang tuntas & 8 & 22 & 32 \\
\hline $\begin{array}{l}\text { Banyak peserta didik yang belum } \\
\text { tuntas }\end{array}$ & 27 & 13 & 3 \\
\hline
\end{tabular}

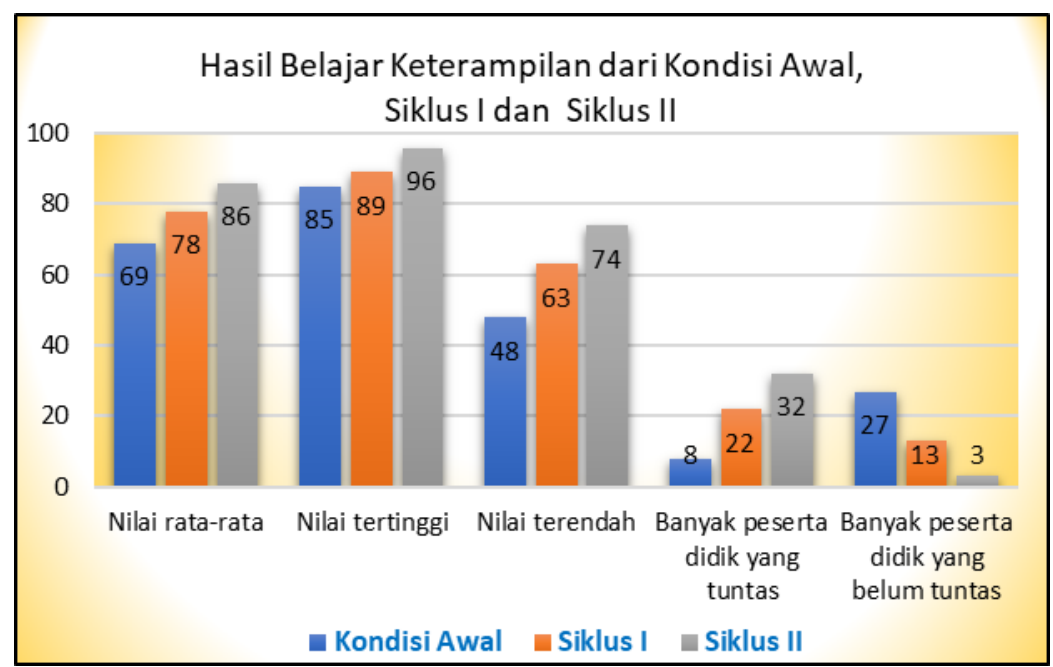

\section{Gambar 2. Hasil Belajar Keterampilan dari Kondisi Awal, Siklus I dan Siklus II}

Berdasarkan paparan tersebut, untuk hasil belajar aspek pengetahuan terjadi peningkatan skor rata-rata dari kondisi awal (72), siklus I (83), dan siklus II (85). Begitu pula hasil belajar aspek keterampilan terjadi peningkatan skor rata-rata dari kondisi awal (69), siklus I (78), dan siklus II (86). Untuk ketuntasan belajar (aspek pengetahuan), banyaknya peserta didik yang tuntas dari kondisi awal sebanyak 8 orang $(22,86 \%)$, meningkat 22 orang $(62,86 \%)$ pada siklus I, meningkat lagi menjadi 32 orang $(91,43 \%)$ pada siklus II. Sedangkan ketuntasan belajar (aspek keterampilan), banyaknya peserta didik yang tuntas dari kondisi awal sebanyak 8 orang $(22,86 \%)$, meningkat 22 orang $(62,86 \%)$ pada siklus I, meningkat lagi menjadi 32 orang $(91,43 \%)$ pada siklus II. Dengan demikian peningkatan dan ketuntasan dua aspek penilaian ini dikatakan sudah memenuhi kriteria indikator keberhasilan, yaitu 
tercapainya ketuntasan klasikal $\geq 85 \%$ dari seluruh peserta didik dan meningkatnya skor ratarata dari satu siklus ke siklus berikutnya, sehingga penelitian tidak perlu lagi dilanjutkan ke siklus III.

\section{Aktivitas Belajar}

Aktivitas belajar setiap peserta didik pada siklus I diperoleh data banyaknya peserta didik berada pada kondisi empat kategori yang ditetapkan. Pada pertemuan 1 peserta didik dengan kategori sangat aktif sebanyak 8 orang $(22,86 \%)$, kategori aktif sebanyak 14 orang (40\%), kategori cukup aktif sebanyak 11 orang $(31,43 \%)$, dan peserta didik yang kurang aktif sebanyak 2 orang $(5,71 \%)$. Sementara pertemuan 2 peserta didik dengan kategori sangat aktif sebanyak 11 orang $(31,43 \%)$, kategori aktif sebanyak 14 orang (40\%), kategori cukup aktif sebanyak 9 orang $(25,71 \%)$, dan peserta didik yang kurang aktif sebanyak 1 orang $(2,86 \%)$.

Aktivitas belajar peserta didik pada siklus II diperoleh data peserta didik dengan kategori sangat aktif sebanyak 13 orang (37,14\%), kategori aktif sebanyak 16 orang $(45,71 \%)$, kategori cukup aktif sebanyak 6 orang $(17,14 \%)$, dan tidak ada peserta didik kategori kurang aktif untuk pertemuan 1. Sementara peserta didik dengan kategori sangat aktif sebanyak 15 orang (42,86\%), kategori aktif sebanyak 18 orang (51,43\%), kategori cukup aktif sebanyak 2 orang $(5,71 \%)$, dan tidak terdapat peserta didik yang kurang aktif untuk pertemuan 2. Perlu ditegaskan bahwa untuk data hasil aktivitas belajar peserta didik antara pertemuan 1 dan pertemuan 2 dalam penelitian ini tidak perlu dirata-ratakan. Karena itu, membandingkan hasil aktivitas belajar antara siklus I dan siklus II cukup merujuk pada aktivitas belajar pertemuan 2 setiap siklusnya.

Lebih jelas, berikut disajikan perbandingan aktivitas belajar peserta didik dari siklus I ke siklus II pada tabel berikut.

Tabel 4. Perbandingan Aktivitas Belajar dari Siklus I ke Siklus II

\begin{tabular}{|l|c|c|c|c|c|c|}
\hline \multirow{2}{*}{ Kriteria } & \multicolumn{2}{|c|}{ Siklus I } & \multicolumn{2}{c|}{ Siklus II } & \multicolumn{2}{c|}{$\begin{array}{c}\text { Persentase } \\
\text { Peningkatan }\end{array}$} \\
\cline { 2 - 7 } & $\begin{array}{c}\text { Banyak } \\
\text { Peserta } \\
\text { Didik }\end{array}$ & $\begin{array}{c}\text { Persentase } \\
(\%)\end{array}$ & $\begin{array}{c}\text { Banyak } \\
\text { Peserta } \\
\text { Didik }\end{array}$ & $\begin{array}{c}\text { Persentase } \\
(\%)\end{array}$ & $\begin{array}{c}\text { Banyak } \\
\text { Peserta } \\
\text { Didik }\end{array}$ & $\begin{array}{c}\text { Persentase } \\
(\%)\end{array}$ \\
\hline Sangat aktif & 11 & 31.43 & 15 & 42.86 & 4 & 11,43 \\
\hline Aktif & 14 & 40 & 18 & 51.43 & 4 & 11,43 \\
\hline Cukup aktif & 9 & 25.71 & 2 & 5.71 & - & - \\
\hline Kurang aktif & 1 & 2.86 & - & - & - & - \\
\hline
\end{tabular}

Berdasarkan tabel tersebut, diperoleh data peserta didik kurang aktif sebanyak 1 orang (2.86\%), cukup aktif 9 orang (25.71\%), aktif 14 orang (40\%) dan sangat aktif 11 orang (31.43\%). Apabila dijumlahkan persentase peserta didik yang aktif (40\%) dan sangat aktif (31.43\%), maka diperoleh persentase aktivitas peserta didik sebesar 71.43\%. Dengan demikian apabila merujuk pada kriteria keaktifan peserta didik yang telah ditetapkan, persentase $71.43 \%$ tergolong kategori aktif.

Meskipun aktivitas belajar peserta didik pada siklus I ini tergolong aktif (sudah mencapai kriteria minimal), penelitian tetap harus dilanjutkan ke siklus II karena setidaknya dengan dua alasan, yaitu (a) pada ketentuan kegiatan penelitian tindakan minimal dilakukan dalam dua siklus, sebagimana dinyatakan oleh Supardi dan Suhardjono (2011) bahwa penelitian tindakan kelas paling sedikit atau tidak kurang dari dua siklus, dan (b) untuk mengetahui peningkatan rata-rata skor pada tiap siklusnya. 
Selanjutnya, pada siklus II diperoleh data peserta didik cukup aktif sebanyak 2 orang (5.71\%), aktif 18 orang (51.43\%), dan sangat aktif 15 orang (42.86\%). Apabila dijumlahkan persentase peserta didik yang aktif $(51.43 \%)$ dan sangat aktif $(42.86 \%)$, maka diperoleh persentase $94.29 \%$. Dengan demikian apabila merujuk pada kriteria keaktifan peserta didik yang telah ditetapkan, persentase $94.29 \%$ tergolong kategori sangat aktif.

Persentase peningkatan peserta didik aktif dari siklus I ke siklus II sebesar $11.43 \%$ (meningkat 4 peserta didik). Kemudian persentase peningkatan peserta didik sangat aktif dari siklus I ke siklus II dengan persentase yang sama, yakni $11.43 \%$ (meningkat 4 peserta didik). Jika disajikan dalam bentuk diagram, maka akan tampak seperti berikut.

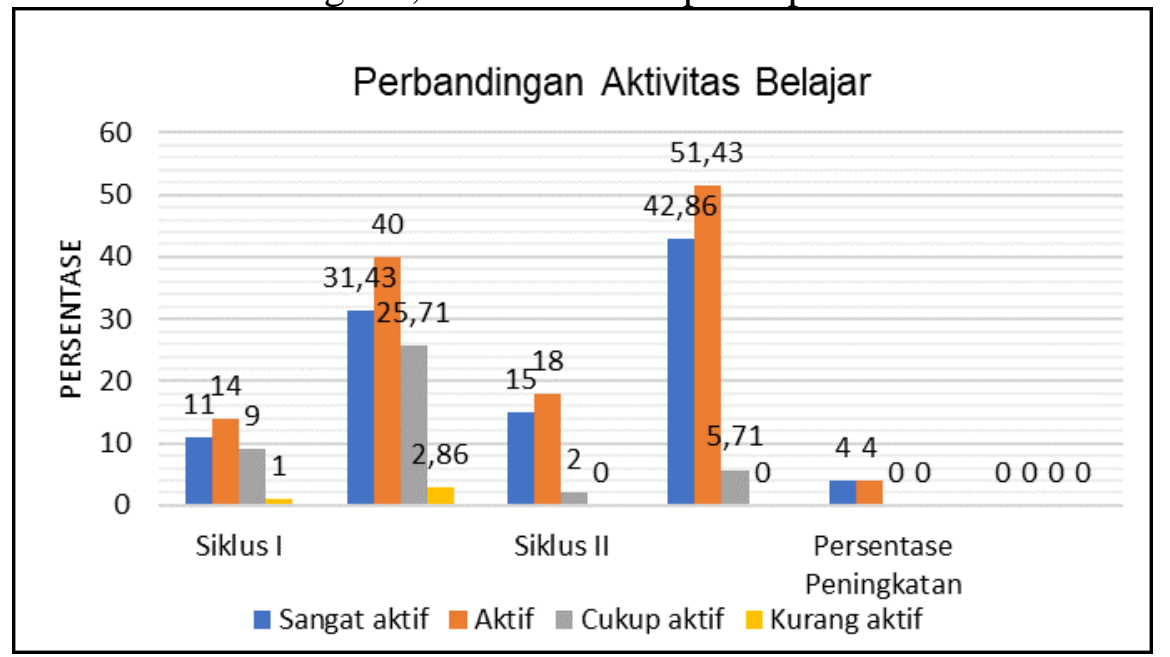

Gambar 3. Perbandingan Aktivitas Belajar dari Siklus I ke Siklus II

Terjadinya peningkatan persentase aktivitas peserta didik selama pembelajaran disebabkan guru telah menerapkan beberapa rekomendasi (hasil diskusi guru peneliti dengan guru kolaborator) yang ditetapkan, yaitu mengingatkan terus peserta didik melalui chat grup untuk menyiapkan segala perlengkapan/media yang mendukung kelancaran pembelajaran secara teknis, mengingatkan terus peserta didik untuk bertanya dan bertanya terhadap permasalahan yang dialami, memberikan penjelasan tertulis di google classroom secara rinci mengenai prosedur kerja LKPD dan disertai contohnya, memantau aktivitas peserta didik secara aktif selama berlangsungnya pembelajaran. Dari aspek peserta didik, sudah tidak canggung lagi menanyakan hal-hal yang belum dipahami, umumnya sudah memahami substansi materi dan masalah yang diangkat untuk dipecahkan berdasarkan analisis data yang dikumpulkan.

Meskipun demikian, karena ini pembelajaran jarak jauh (daring), kendala teknis tetap menghinggapi sebagian (kecil) peserta didik, seperti masalah jaringan dan keterbatasan media yang digunakan, dan tidak cukupnya alokasi waktu pembelajaran (3 jam pelajaran) untuk menyelesaikan tugas dan tes akhir di siklus II. Secara umum penerapan model pembelajaran inkuiri secara daring diterapkan sesuai sintak pembelajaran, dan peserta didik sangat antusias mengikuti pembelajaran.

\section{Kesimpulan}

Kesimpulan yang diperoleh dari hasil penelitian ini adalah; (a) penerapan model pembelajaran inkuiri berbasis google classroom dapat meningkatkan kemampuan berfikir kritis materi munakahat pada peserta didik kelas XII MIPA-4 SMAN 1 Selong tahun pelajaran 2020/2021. Hal ini dibuktikan dengan hasil belajar (pengetahuan) dari kondisi awal 
rata-rata 72, meningkat 83 pada siklus I, dan meningkat lagi menjadi 85 pada siklus II, sedangkan hasil belajar (keterampilan) dari kondisi awal rata-rata 69, meningkat 78 pada siklus I, dan meningkat lagi menjadi 86 pada siklus II. Untuk persentase ketuntasan belajar (pengetahuan), peserta didik yang tuntas dari kondisi awal sebanyak 22,86\% (8 orang), meningkat $62,86 \%$ (22 orang) pada siklus I, dan meningkat lagi menjadi 91,43\% (32 orang) pada siklus II. Ketuntasan belajar (keterampilan), yang tuntas dari kondisi awal sebanyak $22,86 \%$ (8 orang), meningkat $62,86 \%$ (22 orang) pada siklus I, dan meningkat lagi menjadi 91,43\% (32 orang) pada siklus II; dan (b) penerapan model pembelajaran inkuiri berbasis google classroom dapat meningkatkan aktivitas belajar PAI dan Budi Pekerti materi munakahat pada peserta didik kelas XII MIPA-4 SMAN 1 Selong tahun pelajaran 2020/2021. Hal ini dibuktikan adanya peningkatan aktivitas belajar peserta didik, yaitu $71.43 \%$ (kategori aktif) pada siklus I, meningkat menjadi $94.29 \%$ (kategori sangat aktif) pada siklus II.

\section{Saran}

Saran yang dapat disampaikan berdasarkan hasil penelitian ini adalah bagi Guru PAI dan guru mata pelajaran lainnya untuk dapat menerapkan model pembelajaran inkuiri berbasis google classroom, karena hasil penelitian menunjukkan bahwa meningkatnya kemampuan berfikir kritis dan aktivitas belajar, sehingga berdampak pada meningkatnya hasil belajar siswa.

\section{Daftar Pustaka}

Asmuni, A. (2020). Problematika Pembelajaran Daring di Masa Pandemi Covid-19 dan Solusi Pemecahannya. Jurnal Paedagogy, 7(4), 281-288. doi:https://doi.org/10.33394/jp.v7i4.2941

Asmuni, A. (2020). Penerapan Model Pembelajaran Learning Cycle 5e untuk Meningkatkan Aktivitas dan Penguasaan Konsep Siswa Pada Mata Pelajaran PAI dan Budi Pekerti di $\begin{array}{lllll}\text { SMA Negeri } 1 \quad \text { Selong. Jurnal Paedagogy, } & \text { 7(3), }\end{array}$ doi:https://doi.org/10.33394/jp.v7i3.2743

Erwanto, E. (2020). Profil Kemampuan Berpikir Kritis Siswa Pada Konsep Keanekaragaman Hayati Melalui Problem Based Learning. Jurnal Kependidikan: Jurnal Hasil Penelitian dan Kajian Kepustakaan di Bidang Pendidikan, Pengajaran dan Pembelajaran, 6(3), 578-587. doi:https://doi.org/10.33394/jk.v6i3.2916

Harni, H. (2021). Penerapan Model Pembelajaran Inkuiri untuk Meningkatkan Motivasi dan Hasil Belajar Siswa pada Materi Cahaya dan Sifat-Sifatnya di SD Negeri 2 Uebone. Jurnal Paedagogy, 8(2), 181-189. doi:https://doi.org/10.33394/jp.v8i2.3481

Kemdikbud. (2017). Model-model Pembelajaran. Jakarta: Direktorat Pembinaan SMA Dirjen Dikdasmen Kemdikbud

Koroh, T., \& Ly, P. (2020). Pengaruh Model Pembelajaran Problem Based Learning dalam Pembelajaran Pendidikan Kewarganegaraan terhadap Kemampuan Berpikir Kritis Mahasiswa. Jurnal Kependidikan: Jurnal Hasil Penelitian dan Kajian Kepustakaan di Bidang Pendidikan, Pengajaran dan Pembelajaran, 6(1), 126-132. doi:https://doi.org/10.33394/jk.v6i1.2445

Majid, Abdul. (2014). Belajar dan Pembelajaran Pendidikan Agama Islam. Bandung: Remaja Rosdakarya.

Mulyasa, E. (2002). Manajemen Berbasis Sekolah, Konsep Strategi Implementasi. Bandung: Rosda Karya

Nurdyansyah dan Eni Fariatul Fahyuni. (2016). Inovasi Model Pembelajaran Sesuai 
Kurikulum 2013. Sidoarjo: Nizamia Leraning Centre.

Nurkhasanah, S. (2019). Penerapan Model Pembelajaran Inkuiri untuk Meningkatan Aktifitas Belajar Siswa pada Mata Pelajaran Ilmu Pengetahuan Alam Kelas IX.A SMP Negeri 1 Gangga. Jurnal Kependidikan: Jurnal Hasil Penelitian dan Kajian Kepustakaan di Bidang Pendidikan, Pengajaran dan Pembelajaran, 5(1), 47-53. doi:https://doi.org/10.33394/jk.v5i1.1393

Permendiknas Nomor 41 tahun 2007 tentang Standar Proses untuk Satuan Pendidikan Dasar dan Menengah.

Purwanto, M. Ngalim. (2012). Prinsip-prinsip dan Teknik Evaluasi Pengajaran. Bandung: Remaja Rosdakarya.

Sanjaya, Wina. (2006). Strategi Pembelajaran Berorientasi Standar Proses Pendidikan. Jakarta: Kencana.

Supardi dan Suhardjono. (2011). Strategi Menulis Penelitian Tindakan Kelas. Yogyakarta: Andi Offset. 